\title{
ISSR molecular markers for the study of the genetic diversity of Mimosa caesalpiniaefolia Benth.
}

\author{
Marcadores moleculares ISSR para el estudio de la diversidad \\ genética de Mimosa caesalpiniaefolia Benth.
}

\author{
Fernando dos Santos Araújo ${ }^{1}$, Mauro Vasconcelos Pacheco ${ }^{1 *}$, Fábio de Almeida Vieira1, \\ Cibele dos Santos Ferrari ${ }^{1}$, Francival Cardoso Félix ${ }^{1}$, Kyvia Pontes Teixeira das Chagas ${ }^{1}$
}

\begin{abstract}
Knowledge of the genetic diversity of the threatened tree species in the Brazilian semiarid region may contribute to the creation of effective strategies for their preservation and future use. The aim of this study was to select ISSR (Inter-Simple Sequence Repeat) primers capable of detecting genetic polymorphism among Mimosa caesalpiniaefolia Benth. individuals for a study of the genetic diversity of this species. A total of 27 ISSR primers were tested for their ability to amplify genomic DNA of three individuals (bulk); all of them amplified regions between the simple sequence repeats of the genome, however seven ISSR primers showed a good standard of amplification compared to the others. The seven primers selected were used to amplify the genomic DNA of nine individuals and generated a total of 78 loci, of which $52.7 \%$ were polymorphic. The content of polymorphic information of the primers ranged from 0.261 to 0.489 , showing that selected primers are moderately informative; bootstrap analysis determined that 51 loci were enough to estimate the genetic diversity of the samples of individuals. We concluded that the markers generated by the primers UBC 807, UBC 824, UBC 827, UBC 840, UBC 851, UBC 873 and UBC 881 allow detection of the genetic polymorphism among individuals of $M$. caesalpiniaefolia, being useful to determine the genetic diversity of this species.
\end{abstract}

Key words: semiarid, forest species, primers, polymorphism.

\section{RESUMEN}

Conocer la diversidad genética de las especies de árboles forestales en la región semiárida de Brasil puede contribuir al desarrollo de estrategias eficaces para su conservación y uso futuro. El objetivo de este estudio fue seleccionar iniciadores de ISSR (Secuencias Intergénicas Repetidas Simples) capaces de detectar polimorfismo genético entre individuos de Mimosa caesalpiniaefolia Benth. para estudiar la diversidad genética de la especie. Un total de 27 iniciadores ISSR fueron probados por su capacidad para amplificar el ADN genómico de tres individuos. Todos los iniciadores amplificaron secuencias intergénicas repetidas en el genoma, pero siete fueron seleccionados porque presentaron un mejor patrón de amplificación. Los siete iniciadores seleccionados fueron utilizados para amplificar el ADN genómico a partir de nueve individuos y generaron un total de 78 loci, 52,7\% de los cuales fueron polimórficas. El valor del contenido de la información de los iniciadores polimórficos varió de 0,261 a 0,489, demostrando que son moderadamente informativo y el análisis del impulso se determinó que 51 loci fueron suficientes para estimar la diversidad genética de la muestra de los individuos analizados. Los resultados indican que los marcadores generados por los iniciadores UBC 807, UBC 824, UBC 827, UBC 840, UBC 851, UBC 873 y UBC 881 permiten detectar polimorfismo genético entre individuos de M. caesalpiniaefolia y pueden ser utilizados para estimar la diversidad genética para esta especie.

Palabras clave: semiárido, especies forestales, iniciadores, polimorfismo.

\section{Introduction}

The scarceness of forest products in the Brazilian semiarid region caused by deforestation has created the need for preservation, requiring the sustainable use of the economically important native forest species, and in order to do so, the Brazilian government created a unified list of priority species in 2004, believing that cultivation and harnessing of these species could be an alternative to reduce

\footnotetext{
1 Universidade Federal do Rio Grande do Norte, Unidade Acadêmica Especializada em Ciências Agrárias, Programa de PósGraduação em Ciências Florestais, 59280-000, Macaíba-RN, Brasil.

* Corresponding author: pachecomv@ hotmail.com
}

Fecha de Recepción: 1 Junio, 2015.

Fecha de Aceptación: 9 Mayo, 2016. 
the predatory exploitation in natural areas (Pareyn, 2010). Only four of the listed species are cultivated for commerce; among these is Mimosa caesalpiniaefolia Benth., a small-sized tree that occurs naturally in the northeastern semiarid region of Brazil in the states of Ceará and Piauí (Maia, 2004). This is an important species for forest exploitation in the northeastern semiarid region which has advanced studies of harnessing and cultivation, mainly on the exploitation of the wood used as stakes and wooden posts for fences and as an energy source (Pareyn, 2010).

Given this importance the development of studies that can support programs with the objective of maintaining and improving this species genetically are necessary. For both purposes it is relevant to characterize its genetic diversity, because according to Srihari et al. (2013) the existence of genetic diversity in the population to be preserved allows the evolution of new genetic combinations, thus presenting greater ability for evolution and adaptation to changes in environmental conditions, which are important characteristics not only for preservation, but also for genetic improvement.

Currently there are several techniques available that allow the study of genetic diversity in plants, including morphological, biochemical and molecular markers (Vashishtha et al., 2013). The most successful of those that have been developed and put to use in the last two decades are molecular markers based on the polymerase chain reaction technique (PCR), such as Simple Sequence Repeat (SSR), Random Amplified Polymorphic DNA (RAPD) and Inter-Simple Sequence Repeat (ISSR) (Semagn et al., 2006).

In the ISSR technique primers composed of di-, tri-, tetra- or pentanucleotide repetitions are used, with or without a one-to-three nucleotide anchorage system that targets the genomic microsatellite region (Zietjiewicz et al., 1994), not making it necessary to perform previous genomic sequencing. In contrast to other molecular markers, the target sequences of the ISSR primers are abundant throughout the eukaryotic genome and evolve quickly, which consequently helps reveal a much larger number of polymorphic loci than other dominant markers such as RAPD (Ansari et al., 2012).

These characteristics make ISSR markers attractive, especially when the discussion is about species that have not yet been studied from the genetic point of view using molecular markers, such as $M$. caesalpiniaefolia. Thus the aim of this study was to select ISSR primers capable of detecting genetic polymorphisms in $M$. caesalpiniifolia individuals to study their genetic diversity.

\section{Material and Methods}

\section{Collection of plant material and extraction of DNA}

We collected samples of leaves of nine individuals of $M$. caesalpiniaefolia derived from the Área de Experimentação Florestal (5 53' 52.5”' S, 35 21'31.6" W) that belongs to the Unidade Acadêmica Especializada em Ciências Agrárias, Universidade Federal do Rio Grande do Norte (UAECIA/UFRN) in the city of Macaíba, Rio Grande do Norte, Brazil. The samples were packed in a thermal container filled with ice and taken to the Laboratorio de Genética e Melhoramento Florestal (LABGEM) at the UAECIA/UFRN, where they were transferred to tubes containing $2 \%$ CTAB buffered solution and stored at $-20^{\circ} \mathrm{C}$. Genomic DNA was extracted using a modification of the protocol proposed by Doyle and Doyle (1987) and quantified in a microplate spectrophotometer (Epoch ${ }^{\mathrm{TM}}$ ), according to the manufacturer's instructions.

\section{Amplification of DNA with ISSR primers}

The reactions for the amplification of the DNA were carried out in a thermocycler (Veriti ${ }^{\circledR}$ 96-Well) under the following conditions: initial denaturation at $94^{\circ} \mathrm{C}$ for 2 minutes; 37 cycles of 15 seconds at $94^{\circ} \mathrm{C}$ for denaturation, 30 seconds at $47^{\circ} \mathrm{C}$ for primer annealing and 1 minute at $72{ }^{\circ} \mathrm{C}$ for extension, with a final extension for 7 minutes at $72{ }^{\circ} \mathrm{C}$. The PCR amplifications were carried out in $12 \mu \mathrm{L}$ reaction containing $2.0 \mu \mathrm{L}$ diluted DNA (1:50) added to $10.0 \mu \mathrm{L}$ of mixed reaction $[0.33 \mu \mathrm{M}$ primers; $1.2 \mu \mathrm{L}$ PCR buffer (Buffer IC Phoneutria ${ }^{\circledR}$ ); 0.25 mg.mL ${ }^{-1}$ BSA; 2.0 $\mathrm{mM} \mathrm{MgCl}$; $0.25 \mathrm{mM}$ dNTPs; 0.5 U Taq DNA polymerase]; the final volume was completed with ultra-pure water.

PCR products were stained with bromophenol associated with GelRed ${ }^{\mathrm{TM}}$ and separated by horizontal electrophoresis in agarose gels $(1.5 \% \mathrm{w} / \mathrm{v})$ immersed in TAE $1 \mathrm{X}$ buffer (Tris-Acetate-EDTA) at constant voltage $(100 \mathrm{~V})$ for approximately three hours. A negative control containing only the PCR mix and 
a standard molecular weight with 1000 base pairs (bp) (K181 DNA Ladder Invitrogen ${ }^{\circledR}$ ) were used in each electrophoresis. The gels were photographed under ultraviolet light in a photo-documentation system (E-Box VX2).

We tested 27 ISSR primers (University of British Columbia - UBC) using genomic DNA in bulk of three $M$. caesalpiniaefolia individuals sampled randomly. We selected the primers that presented the best amplification standards (unmistakable, reproducible loci with good resolution quality and in large number), which were used to amplify the genomic DNA of the nine sampled individuals.

Each primer was evaluated with regard to the total number amplified loci, total number of polymorphic loci, rate of polymorphism and the value of the content of polymorphic information according to equation (1), proposed by Anderson et al. (1993):

$$
P I C_{i}=1-\sum{ }_{j=1}^{n} P_{i j}^{2}
$$

Where: $P_{i j}$ is the frequency of the allele " $j$ " in primer " $i$ ".

Allele frequencies were obtained using presence (1) and absence (0) data of the amplified loci for each primer in the nine individuals using the Popgene version 1.3 software (Yeh et al., 1997).

\section{Number of loci sufficient for the study of genetic diversity}

The determination of the sufficient number of loci to obtain precise estimates for genetic diversity of the sampled individuals was performed by bootstrap implemented in the Genes software (Cruz, 2001). Using a binary matrix of presence (1) and absence (0) of the amplified loci the genetic distance (Nei, 1978) for each pair of individuals was estimated. We then estimated for each pair of individuals values of simulated genetic distance after re-sampling using different numbers of loci $(1 ; 6 ; 11 ; \ldots ; 78)$ with 10,000 permutations. With the values of simulated genetic distance we generated the matrices that were correlated $(r)$ with the original genetic distance matrix. The adjustment between the two matrices was verified by the Kruskal stress value (Kruskal, 1964). The number of loci was considered sufficient to carry out the estimates of genetic diversity when the stress reached a value below 0.05 and the correlation was close to the maximum value $(r=1.0)$.
Table 1. ISSR primers with their respective sequences of nucleotides and total number of amplified loci.

\begin{tabular}{clr}
\hline $\begin{array}{c}\text { ISSR } \\
\text { Primer }\end{array}$ & \multicolumn{1}{c}{$\begin{array}{c}\text { Sequence of } \\
\text { nucleotides (5' - 3') }\end{array}$} & $\begin{array}{c}\text { Total number } \\
\text { of loci }\end{array}$ \\
\hline UBC 807 & AGAGAGAGAGAGAGAGT & 9 \\
UBC 808 & AGAGAGAGAGAGAGAGC & 5 \\
UBC 809 & AGAGAGAGAGAGAGAGG & 5 \\
UBC 810 & GAGAGAGAGAGAGAGAT & 9 \\
UBC 813 & CTCTCTCTCTCTCTCTT & 9 \\
UBC 818 & CACACACACACACACAG & 10 \\
UBC 821 & GTGTGTGTGTGTGTTT & 2 \\
UBC 822 & TCTCTC TCTCTCTCTCA & 7 \\
UBC 824 & TCTCTCTCTCTCTCTCG & 8 \\
UBC 825 & ACACACACACACACACT & 7 \\
UBC 826 & ACACACACACACACACC & 4 \\
UBC 827 & ACACACACACACACACG & 12 \\
UBC 829 & TGTGTGTGTGTGTGGC & 6 \\
UBC 830 & TGTGTGTGTGTGTGGG & 8 \\
UBC 840 & GAGAGAGAGAGAGAGAYT & 11 \\
UBC 841 & GAGAGAGAGAGAGAGAYC & 10 \\
UBC 842 & GAGAGAGAGAGAGAGAYG & 4 \\
UBC 843 & CTCTCTCTCTCTCTCTRA & 5 \\
UBC 844 & CTCTCTCTCTCTCTCTRC & 7 \\
UBC 851 & GTGTGTGTGTGTGTGTYG & 9 \\
UBC 857 & ACACACACACACACACYG & 6 \\
UBC 859 & TGTGTGTGTGGTGTGRC & 10 \\
UBC 860 & TGTGTGTGTGTTGTGRA & 7 \\
UBC 862 & AGCAGCAGCAGCAGCAGC & 8 \\
UBC 873 & GACAGACAGACAGACA & 11 \\
UBC 880 & GGAGAGGAGAGGAGA & 6 \\
UBC 881 & GGGTGGGGTGGGGTG & 9 \\
\hline & &
\end{tabular}

$\mathrm{R}$, purine (A or $\mathrm{G}), \mathrm{Y}$, pyrimidine (C or $\mathrm{T})$.

\section{Results and Discussion}

All 27 primers tested amplified sequences between simple repeated regions (microsatellites) in the genome of M. caesalpiniaefolia (Table 1). The number of loci amplified per primer varied from 2 to 12 ; most of them amplified regions with 5 to 10 loci.

The primers selected because they had good amplification compared to the others were UBC 807, UBC 824, UBC 827, UBC 840, UBC 851, UBC 873 and UBC 881 . By evaluating the amplification standard of these primers using genomic DNA of nine individuals (Table 2) we found that only UBC 807, UBC 881 and UBC 840 amplified the same number of loci observed during the pre-selection, while UBC 851 amplified a smaller number and UBC 824, UBC 827 and UBC 873 amplified a larger number of loci. This difference in the profile of amplification of the primers is related to the kind of DNA sampled, because according to Yanaka et al. (2005), using DNA samples in bulk, alleles with low frequency in the population cannot be amplified. 
Table 2. Total number of loci, number of polymorphic loci, rate of polymorphism and value of the polymorphic information content (PIC) of seven ISSR primers in a set of nine M. caesalpiniaefolia individuals.

\begin{tabular}{lcccc}
\hline Primer & Total number of loci & Total number of polymorphic loci & Rate of polymorphism & PIC value \\
\hline UBC 807 & 9 & 5 & 55.6 & 0.451 \\
UBC 824 & 16 & 9 & 56.3 & 0.450 \\
UBC 827 & 14 & 4 & 28.6 & 0.261 \\
UBC 840 & 11 & 7 & 63.6 & 0.334 \\
UBC 851 & 7 & 3 & 42.9 & 0.381 \\
UBC 873 & 12 & 8 & 66.7 & 0.489 \\
UBC 881 & 9 & 5 & 55.6 & 0.416 \\
\hline Average & 11 & 6 & 52.7 & 0.397 \\
\hline Total & 78 & 41 & - & - \\
\hline
\end{tabular}

The analysis of nine individuals with seven primers showed a total of 78 loci, with an average of 11 loci per primer (Table 2). The average number of loci per primer obtained in this study approached the numbers observed in Pongamia pinnata (L.) Pierre (10.75 loci) (Kesari et al., 2010), Praecox chimonanthus (L.) Link (10.45 loci) (ZHAO et al., 2007) and Spondias sp. (10 loci) (Santana et al., 2011), suggesting that the average number of amplified loci by the primers selected for $M$. caesalpiniaefolia may be considered satisfactory.

The seven primers revealed a total of 41 polymorphic loci, that is, $52.7 \%$ of the total of amplified loci. However, the ability to detect polymorphism was quite variable among the primers, which varied from $28.6 \%$ (UBC 827) to $66.7 \%$ (UBC 873 ) with an average of $52.7 \%$ polymorphism per primer. This rate of polymorphism is low compared to values obtained with other sets of ISSR primers in Hagenia abyssinica (Bruce) J. F. Gmel. (81.0\%) (Feyissa et al., 2007), Spondias sp. (80.0\%) (Santana et al., 2011), Thuja sutchuenensis Franch. (76.1\%) (Liu et al., 2013), Larix gmelinii (Rupr.) (98.8\%) (Zhang et al., 2013) and Erythrina velutina Willd (98.0\%) (Gonçalves et al., 2014).

However, this does not necessarily mean that the primers evaluated for M. caesalpiniaefolia in this study amplify regions with low polymorphism. The rate of primer polymorphism may vary as a function of the population or group of individuals being evaluated, as shown by Oliveira et al. (2010) in populations of Carapichea ipecacuanha (Brot.) L. derived from different geographic regions, Yiing et al. (2014) in planted and natural forests of Neolamarckia cadamba (Roxb.) Bosser, Qian et al. (2013) between populations of Calanthe tsoongiana Tang \& F. T. Wangand and by Dai et al. (2013) between populations of Madhuca hainanensis Chun \& F. C. How.

The content of polymorphic information showed values from 0.261 (UBC 827) to 0.489 (UBC 873); the average rate was 0.397 for the combination of the seven primers, which according to Botstein et al. (1980) can be classified as moderately informative (Table 2). This evaluation confirms that the selected primers can be used to estimate the genetic diversity of M. caesalpiniaefolia, since ISSR primers classified as moderately informative have been used successfully in other species such as Pongamia pinnata (L.) Pierre (Kesari et al., 2010), Dioscorea spp. (Velasco-Ramírez et al., 2014), Quercus brantii Lindl. (Alikhani et al., 2014) and Trifolium ssp. (Aryanegad et al., 2013).

Through bootstrap analysis we were able to estimate the number of loci sufficient for the study of genetic diversity of $M$. caesalpiniaefolia (Figure 1). We have verified that, with the increase of loci analyzed in re-sampling there was an increase

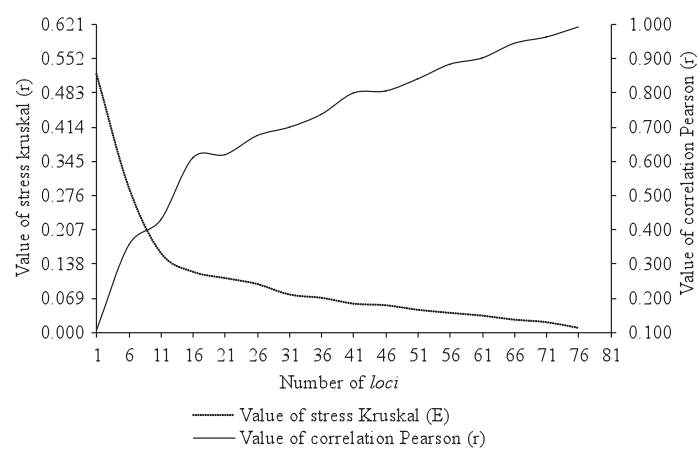

Figure 1. Values of the Pearson correlation (r) and Kruskal stress (E) as a function of the number of ISSR loci used to estimate the genetic diversity of nine $M$. caesalpiniaefolia individuals. 
of the values of correlation and a reduction of the Kruskal stress values. When re-sampling was done with 51 loci, the stress was 0.046 and the correlation coefficient was 0.840 .

Stress values below 0.05 indicate high precision estimates (Kruskal, 1964) and $r$ values close to 1.0 indicate high positive correlation between the original genetic distance matrix and the simulated genetic distance matrix. Thus we can presume that the number of loci used (78) to carry out the genetic diversity estimates for the sampled individuals was sufficient.

The definition of the minimum number of ISSR loci for the study of genetic diversity through bootstrap analysis has been carried out for several taxa, such as Spondias sp. (Santana et al., 2011), Erythrina velutina Willd. (Gonçalves et al., 2014) and orchids like Cattleya and Brassavola (Fajardo et al., 2014). Its use has contributed to optimize the use of resources and time, translated into a smaller number of genomic sample representatives to characterize genetic diversity (Gonçalves et al., 2014).

\section{Conclusion}

We conclude that the markers generated by the primers UBC 807 , UBC 824, UBC 827, UBC 840 , UBC 851 , UBC 873 and UBC 881 allow us to detect the genetic polymorphism among individuals of $M$. caesalpiniaefolia, being useful to determine the genetic diversity of this species.

\section{Acknowledgements}

The authors thank the Fundação de Apoio à Pesquisa do Estado do Rio Grande do Norte (FAPERN), CAPES and the Laboratório de Genética e Melhoramento Florestal (LABGEM/ UAECIA/UFRN) for helping in the development of research.

\section{Literature Cited}

Alikhani, L.; Rahmani, M.; Shabanian, N.; Badakhshan, H.; Khadivi-Khub, A.

2014. Genetic variability and structure of Quercus brantii assessed by ISSR, IRAP and SCoT markers. Gene, 552 (1): 176-83.

Anderson, J.A.; Churchill, G.A.; Autrique, J.E.; Tanksley, S.D.; Sorrells, M.E.

1993. Optimizing parental selection for genetic linkage maps. Genome, 36: 181-186.

Ansari, S.A.; Narayanan, C.; Wali, S.A.; Kumar, R.; Shukla, N.; Rahangdale, S.K.

2012. ISSR markers for analysis of molecular diversity and genetic structure of Indian teak (Tectona grandis $\mathrm{Lf}$ ) populations. Annals of Forest Research, 55 (1): 11-23.

Aryanegad, P.; Farshadfar, E.; Safari, H.; Shirvani, H.

2013. Application of ISSR molecular markers in genetic diversity of three Trifolium species. Journal of Biodiversity and Environmental Sciences, 3 (12): 78-84.

Botstein, D.; White, R.L.; Skolnick, M.; Davis, R.W.

1980. Construction of a genetic linkage map in man using restriction fragment length polymorphisms. The American Journal of Human Genetics, 32: 314-331.

Cruz, C.D.

2001. Programa GENES: versão Windows. Editora UFV, Viçosa, 642 pp.

Dai, Z.; Si, C.; Zhai, D.; Huang, P.; Qi, S.; Zhong, Q.; Hu, X.; Li, H., Du, D.

2013. Human impacts on genetic diversity and differentiation in six natural populations of Madhuca hainanensis, an endemic and endangered timber species in China. Biochemical Systematics and Ecology, 50: 212-219.

Doyle, J.J.; Doyle, J.L.

1987. Isolatin of plant DNA from fresh tissue. Focus, 12 (1): 13-15.
Fajardo, C.G.; Vieira, F.A.; Molina, W.F.

2014. Interspecific genetic analysis of orchids in Brazil using molecular markers. Plant Systematic and Evolution, 300 (8): 1825-1832.

Feyissa, T.; Nybom, H.; Bartish, I.V.; Welander, M. 2007. Analysis of genetic diversity in the endangered tropical tree species Hagenia abyssinica using ISSR markers. Genetic Resources and Crop Evolution, 54: 947-958.

Gonçalves, L.O.; Pinheiro, J.B.; Zucchi, M.I.; Silva-Mann, R. 2014. Caracterização genética de mulungu (Erythrina velutina Willd.) em áreas de baixa ocorrência. Revista Ciência Agronômica, 45 (2): 290-298.

Kesari, V.; Madurai, S.V.; Parida, A.; Rangan, L.

2010. Molecular marker-based characterization in candidate plus trees of Pongamia pinnata, a potential biodiesel legume. AoB Plants, 17 (3): 342-349.

Kruskal, J.B.

1964. Multidimensional scaling by optimizing goodness of fit to a no metric hypothesis. Psychometrika, 29 (1): 1-27.

Liu, J.; Shi, S.; Chang, E.; Yang, W.; Jiang, Z.

2013. Genetic diversity of the critically endangered Thuja sutchuenensis revealed by ISSR markers and the implications for conservation. International Journal of Molecular Sciences, 14 (7): 14860-14871.

Maia, G.N.

2004. Caatinga: árvores e arbustos e suas utilidades. D \& Z, São Paulo, 413 pp.

Nei, M.

1978. Estimation of average heterozygosity and genetic distance from a small number of individuals. Genetics, 89: 583-590.

Oliveira, L.O.; Venturini, B.A.; Rossi, A.A.B.; Hastenreiter, S.S. 2010. Clonal diversity and conservation genetics of the medicinal plant Carapichea ipecacuanha (Rubiaceae). Genetics and Molecular Biology, 33 (1): 86-93. 
Pareyn, F.G.C.

2010. A importância da produção não madeireira na Caatinga. In: Gariglio, M.A. et al. (Orgs.) Uso sustentável e conservação dos recursos florestais da caatinga. Serviço Florestal Brasileiro, Brasília, 2010, 139 pp.

Qian, X.; Wang, C.; Tian, M.

2013. Genetic diversity and population differentiation of Calanthe tsoongiana, a rare and endemic orchid in China. International Journal of Molecular Sciences, 14: 20399-20413.

Santana, I.B.B.; Oliveira, E.J.; Soares Filho, Ws.; Ritzinger, R.; Amorim, E. P.; Costa, M.A.P.C.; Moreira, R.F.C.

2011. Variabilidade genética entre acessos de umbu-cajazeira mediante análise de marcadores ISSR. Revista Brasileira de Fruticultura, 33 (3): 868-876.

Semagn, K.; Bjornstad, A.; Ndjiondjop, M.N.

2006. An overview of molecular marker methods for plants. African Journal of Biotechnology, 5 (25): 2540-2568.

Srihari, J.M.; Verma, B.; Kumar, N.; Chahota, R.K.; Singh, V.;

Rathour, R.; Singh, S.K.; Sharma, S.K.; Sharm, T.R.

2013. Analysis of molecular genetic diversity and population structure in sea buckthorn (Hippophae spp L.) from northwestern Himalayan region of India. Journal of Medicinal Plants Research, 7 (43): 3183-3196.

Vashishtha, A.; Jehan, T.; Lakhanpaul, S.

2013. Genetic diversity and population structure of Butea monosperma (Lam.) Taub. - a potential medicinal legume tree. Physiology and molecular biology of plants, 19 (3): 389-397.

Velasco-Ramírez, A.P.; Torres-Morán, M.I.; Molina-Moret, S.;

Sánchez-González, J.J.; Santacruz-Ruvalcaba, F.

2014. Efficiency of RAPD, ISSR, AFLP and ISTR markers for the detection of polymorphisms and genetic relationships in camote de cerro (Dioscorea spp.). Electronic Journal of Biotechnology, 17 (2): 65-71.

Yanaka, Y.F.; Dall'Agnol, M.; Schifino-Wittmann, M.T.; Dias, P.M.B.

2005. Variabilidade genética em populações naturais de Bromus auleticus Trin. ex Nees (Poaceae) com base em isoenzimas e marcadores RAPD. Revista Brasileira de Zootecnia, 34: 1897-1904.

Yeh, F.C.; Yang, R.C.; Boyle, T.B.J.; Ye, Z.H.; Mao, J.X.

1997. Pop-gene, theuser-friendly shareware for population genetic analysis molecular biology and biotechnology center. Molecular Biology and Biotechnology Center, University of Alberta, Ed-monton, Alberta, Canada.

Yiing, T.S.; Fu, C.S.; Seng, H.W.; Ling, P.S.

2014. Genetic diversity of Neolamarckia cadamba using dominant DNA markers based on inter-simple sequence repeats (ISSRs) in Sarawak. Advances in Applied Science Research, 5 (3): 458-463.

Zhang, L.; Zhang, H.G.; Li, X.F.

2013. Analysis of genetic diversity in Larix gmelinii (Pinaceae) with RAPD and ISSR markers. Genetics and molecular research, 12 (1): 196-207.

Zhao, K.; Zhou, M.; Chen, L.

2007. Genetic diversity and discrimination of Chimonanthus praecox (L.) link germplasm using ISSR and RAPD markers. Hort Science, 42 (5): 1144-1148.

Zietjiewicz, E.; Rafalski, A.; Labuda, D.

1994. Genome fingerprinting by simple sequence repeat (SSR)-anchored polymerase chain reaction amplification. Genomics, 20 (1): 176-183. 